\title{
UTILITARIANISM, POVERTY AND DEVELOPMENT OF DISABLED PEOPLE
}

\author{
Inacia Sátiro Xavier de França ${ }^{1}$
}

Lorita Marlena Freitag Pagliuca ${ }^{2}$

França ISX, Pagliuca LMF. Utilitarianism, poverty and development of disabled people. Rev Latino-am Enfermagem 2007 setembro-outubro; 15(número especial):857-63.

This study aims to analyze the influences of human development factors in the experience of disabled people based on social scenarios of inequality. The data collected were standardized and allocated in thematic categories. The analysis was based on liberal utilitarianism. The conclusion is that there is legislation in Brazil that guarantees the disabled people's development in areas such as health, education and work. However despite the attempts of decision makers in combating discriminatory behaviors and the theory based on equity, these people still face difficulties in breaking the barrier of poverty and achieving all humans rights deserved.

DESCRIPTORS: poverty; human development; social justice; ethics

\section{UTILITARISMO, POBREZA Y DESARROLLO DE LOS PORTADORES DE DEFICIÉNCIA}

Este taller analiza la influencia de los factores de desarrollo humano en la vida de los portadores de deficiencia, tomando por base los escenarios sociales de desigualdad. Los datos colectados han sido puestos en patrones y alojados en núcleos temáticos. El análisis se ha fundamentado en el utilitarismo liberal. Se concluyó que, en Brasil, los portadores de deficiencia conquistaron legislación que asegura el su desarrollo, sin embargo enfrenten dificultades para superar la pobreza y alcanzar desarrollo; que los factores que limitan su desarrollo se localiza en el campo de la salud, de la educación y del trabajo. Y aún existen resquicios de prejuicio que se encargan de legitimar la práctica de la equidad en los moldes del utilitarismo liberal.

DESCRIPTORES: pobreza; desarrollo humano; justicia social; ética

\section{UTILITARISMO, POBREZA E DESENVOLVIMENTO DOS PORTADORES DE DEFICIÊNCIA}

Objetivou-se analisar a influência dos fatores de desenvolvimento humano na vivência dos portadores de deficiência, tomando por base os cenários sociais de desigualdade. Os dados coletados foram padronizados e alocados em núcleos temáticos. A análise fundamentou-se no utilitarismo liberal. Conforme se concluiu, no Brasil, os portadores de deficiência conquistaram legislação que assegura seu desenvolvimento, mas enfrentam dificuldades para superar a pobreza e alcançar esse desenvolvimento. Os fatores que limitam seu desenvolvimento situam-se no campo da saúde, da educação e do trabalho. E ainda existem resquícios de preconceito tendentes a legitimar a prática da equidade nos moldes do utilitarismo liberal.

DESCRITORES: pobreza; desenvolvimento humano; justiça social; ética

${ }^{1}$ PhD in Nursing, Professor of the Nursing Graduate Program, Paraíba State University, Brazil, e-mail:isxf@oi.com.br; ${ }^{2}$ PhD in Nursing, Professor Department of Nursing, Ceará Federal University, Brazil, e-mail:pagliuca@ufc.br 


\section{INTRODUCTION}

Latin America is known as the area with the most unequal resource distribution. This phenomenon is a consequence of its position within the global economic system, as well as the internal colonialism that permits racial categories and government structures to persist ${ }^{(1)}$. The social impact exerted by the crisis of capitalism, economic globalization and the changes in economic production processes have caused consequences, such as increasing unemployment, poverty, social inequities, and, consequently, the exclusion of individuals who are considered unnecessary to the production universe.

In Brazil, the National Coordination Office for the Integration of People with Disabilities (CORDE), affiliated with the Ministry of Justice, enacts specific legislation with a view to creating new institutional agreements articulated with creative forms of social participation, to ensure the achievement of citizenship through justice and social inclusion. The following bills are highlighted among the norms: Law $7.853^{(2)}$, Decree $3.298^{(3)}$, which regulates Law 7.853, about the National Policy for the Integration of People with Disabilities and consolidated the protection standards; and Law $10.098^{(4)}$, which establishes general norms and criteria for the promotion of accessibility to persons with disabilities or reduced mobility.

Taking into consideration the possibility of omitting people with disabilities from the job market and that causal factors of unemployment are the major determinant of the poverty level in which they live, it should be questioned: What is the socioeconomic situation of people with disabilities in the current Brazilian conjuncture?

The subject "poverty and development of disabled persons" was chosen to analyze the influence of disabled people's development factors in settings of social inequity. The authors work with the hypothesis that, in Brazil, institutions create instruments to stimulate the construction of an inclusive society: one that enables disabled individuals to develop their potentials. However, liberal utilitarianism hinders that construction and promotes deceptive conceptions of social well-being.

\section{METHOD}

This study is a bibliographic review on the subject "poverty and development of disabled persons". The period from 1981 to 2006 was studied, justified by the fact that the United Nations declared 1981 to be The International Year of Disabled Persons.

Data were collected in the databases LILACS and MEDLINE, using the following keywords: poverty, human development, social justice, and ethics. Data concerning the legislation for social inclusion of disabled persons were obtained from the Brazilian Ministry of Justice website (http://www.sedh.gov.br) and from bibliographic references of authors who focused their work on the influence of utilitarianism in social conjunctures.

In order to comply with the study objectives, as to the composition of the corpus, preference was given to texts written in Portuguese and focusing on the socioeconomic status of disabled persons. In national nursing journals, no articles addressing this subject were found.

After locating and selecting the material, a careful reading was done to obtain the main ideas and concepts the authors used to formulate the ideas regarding poverty and human development and social policies for the inclusion of disabled persons.

Subsequently, the data were standardized and thematic groups were created. After this step, an analysis was performed to articulate the situations described in the thematic groups with the ideas in the book Utilitarianism ${ }^{(5)}$. Finally, conclusions were drawn about the socioeconomic conditions of disabled persons and interventions were suggested with a view to reducing poverty and improving development.

\section{DETERMINANT ASPECTS OF POVERTY AND SOCIAL INQUITY}

Poverty can be defined as the need for essential goods and services. It means the impossibility to meet needs of good nutrition, health, clothing, housing, as well as having economic resources, good education levels, employment, high self-esteem, sociability and social participation ${ }^{(6)}$.

To categorize poverty, certain criteria, called indicators, are used: absolute poverty, when the person has a daily consumption of calories below what is needed, i.e., less than 2,000 or 2,500 kilocalories, and lives with less than one dollar a day; relative poverty is that in which the individual lives with one to two dollars per day ${ }^{(7)}$. These situations are identified through indicators, such as the Gini coefficient. This 
parameter measures income concentration in a certain population. Therefore, income concentration is directly proportional to how close one is to the coefficient value. Hence, the closer one is to zero, the lower the income concentration. When this is the case, economic equity is higher in that population ${ }^{(8)}$.

In addition to the determinant factors of poverty, economic globalization is also marked by its undesirable effects: poverty-exclusion. This economic system is primarily founded on the ideas of liberal utilitarianism, an ethical current that stimulates free competition as a tool to boost social development ${ }^{(9)}$. In the $18^{\text {th }}$ century, this ethical current brought about a liberal State, a movement against the absolutist State and its interference in free markets ${ }^{(10)}$.

Economic liberalism expanded in the $18^{\text {th }}$ and $19^{\text {th }}$ centuries and contributed to advances in industrialization and technology, as well as to the increased struggle to dominate world markets and differences between major powers. Hence, the movement produced the following consequences: economic depression, enhancement of social theories, claims by workers' unions for legislation to protect social rights, workers' rights, and changes in work relations. This fact stimulated State intervention in the sense of economy recovering by implementing a new capitalist phase marked by the Welfare State, a policy of social well-being inspired by the ideas of John Maynard Keynes ${ }^{(11)}$

In the late 1970's and early 1980's, the Keynesian policy, which was already accused of causing inflation, suffered the impact of conservative action by the governments of England, United States and Germany, which put into practice neoliberal ideas based on the idea of breaking norms, as well as privatization and commercial opening. Due to interdependent relations among countries, this policy spread across the continents in a way that in the early 1990's, Brazil surrendered to this policy because of its foreign debt ${ }^{(12)}$.

As reality shows, economic globalization produced benefits for many countries, but not for all. Moreover, although global poverty has been reduced, it remains a problem that demands intervention, since there are 1,100 million people living in absolute poverty; more than 800 million are malnourished; 50 thousand people die everyday, mostly women and children; and approximately 11 million children die before completing five years of age ${ }^{(7)}$.

Human development is evaluated by measuring poverty, illiteracy, education, life expectancy and births in a certain country compared to other countries in the world, based on the Human Development Index (HDI). The HDI is considered low when between 0 and 0.499; average, when between 0.500 and 0.799 ; and high when between 0.800 and 1. Since 1993, the United Nations has used this index in its annual report. The data show that there are 75 countries with a high degree of human development. Among the 177 evaluated countries, Brazil reached an index of 0.792 in 2006. Hence, it ranked 69th among the other countries ${ }^{(7)}$.

\section{EXPERIENCES OF DISABLED PERSONS IN BRAZIL}

According to the year 2000 census in Brazil, there are 24.5 million people with some sort of disability. The Brazilian Northeast has the highest percentage, especially in the states of Paraiba (18.7\%), Rio Grande do Norte (17.6\%), Piaui (17.6\%), Pernambuco $(17.4 \%)$, and Ceara $(7.3 \%)$. The states with the lowest percentage are: Sao Paulo (11.3\%), Roraima (12.5\%), Amapa (13.2\%), Parana (13.5\%), and the Distrito Federal (13.4\%). Still considering this population, 19.8 million live in the urban area and 4.8 million in the rural area. Regarding the type of disability, results show that $48 \%$ present physical disability, $22.9 \%$ motor disability, $16.7 \%$ hearing disability, $8.3 \%$ mental disability and $4.1 \%$ visual disability ${ }^{(13)}$. The main cause of disabilities is the lack of care during pregnancy. This precarious care to pregnant women is responsible for $16.8 \%$ of the cases, followed by genetic problems $(16.6 \%)^{(14)}$.

In terms of gender, $13,179,712$ are women and $11,420,544$ are men. Among the nine million disabled people in the job market, 5.6 million are men and 3.4 million are women, 4.9 million of whom earn less than two minimum wages $^{(13-14)}$.

In the year 2000, in terms of instruction, the access of disabled individuals between 7 and 14 years old was $88.6 \%$, dropping to $74.9 \%$ for people with severe disability, and to $61 \%$ for people with permanent physical disability. As for people aged 15 or more, the illiteracy rate was $72 \%$. For people in this same age range with up to three years of schooling, the rate was $32.9 \%{ }^{(13)}$.

Taking into consideration that, in Brazil, the National Coordination Office for the Integration of People with Disabilities is the institution responsible 
for managing the policies directed at including these people to preserve their rights and promote citizenship; and that the latest Brazilian HDI (0.792) refers to the collective population; that this index expresses poverty, lack of job opportunities; and that this context may trigger social discrimination against vulnerable groups, one may question: Which factors continue determining that disabled persons live in a precarious situation, i.e., one of poverty-exclusion? What are the challenges involved in the construction of spaces to develop those people?

\section{FACTORS DETERMINING POVERTY- EXCLUSION OF DISABLED PERSONS}

Based on the liberal utilitarian version ${ }^{(5)}$ of theological ethics, as it is learned in neocapitalist societies like Brazil, social justice is constructed based on the degree of liberty associates have to develop, most efficiently, the productive forces of this society, while state intervention is reduced. In this form of action, justice has the function to preserve social order by means of an equal treatment for equal people and different treatment for different people, depending on the degree of that difference ${ }^{(5)}$.

However, the disparity of monetary income alone is not responsible for the inequity in the quality of life of disabled persons, neither for the diversity in their limitations and incapacities, nor their inherent gender disparity. The degradation of theses individuals' quality of life is linked to other factors, such as (lack of) education, unemployment, criminality and violence, the impact of pollution on the environment, and difficulties to access health care services. These factors particularly affect the poor.

Hence, despite recognizing that there are continuous social actions to meet the needs of those persons considered excluded, it is impossible to disregard the discontinuities and ruptures in intervention models. In the case of disabled persons, literature reports confirm this statement.

There aren't schools for the deaf in the society. Schools are made for listeners; there are no deaf teachers. The deaf do not improve, do not learn. Society is far too difficult for the deaf because there is no LIBRAS (Brazilian sign language). LIBRAS must be taught. If I arrive and the listener does not know LIBRAS... Ah! Never mind... I have suffered too much. I spend too much time going through first to fourth grade. The government should be blamed for having no LIBRAS. I reached the seventh grade, then went back to first grade. The government is to blame. The government is wrong, the government's thinking is wrong. I complete the seventh grade. I am late because of having to go back to the first grade. There are companies that will not offer a job. There are companies with very wrong thinking. There are companies that want to offer jobs but do not know what to do. There are companies that think differently. I wish everyone could work, so everyone could be happy. So they could all grow, develop. There are many unhappy disabled persons ${ }^{(15)}$.

This conjuncture does not go by unnoticed by the Ministry of Social Action, neither by many managers of governmental and non-governmental institutions. Such social actors work to find the concreteness and efficacy of social welfare, consolidated in the Organic Law of Social Welfare (OLSW) and in the National Policy of Social Welfare (NPSW), whose mission is to ensure social protection to Brazilian citizens living in precarious situations $^{(16)}$. However, advancements due to NPSW remain incipient, since the level of inequity in Brazil, which has a $1 \%$ economic growth rate, reduces poverty by less than $1 \%{ }^{(17)}$.

Hence, interventions in health are at times based on pity and compassion for the poor, by reproducing subordination relationships, hiding coercion strategies and making legitimate and equalitarian social bonds unfeasible; and, at others, respecting the differences of plurality. In any of these forms of assistance, inequity prevails, since equity is not a central value ${ }^{(18)}$.

\section{CHALLENGES IN THE CONSTRUCTION OF SPACES FOR THE DEVELOPMENT OF DISABLED PERSONS}

Among the norms that ensure spaces for the development of people with disabilities, the following are highlighted: the Brazilian Constitution of $1988^{(19)}$, which defines social security as an integrated group of initiative actions by public powers and the society, which ensure health, security, and social welfare rights; Law 8.742/93(16) , about the National Policy of Social Welfare, which integrates public and social actions to guarantee that basic needs are met, and that, in a non-contributive way, the minimum social needs to deal with poverty be attended; Law 7.853/ $89^{(2)}$; Decree 3.298/99(3), and the Statute of Persons with Special Needs, presented by Bill 3.638/00(20).

The Statute reinforces the achievements reached through the movement by people with special 
needs. Among other regulations, it makes feasible the participation of disabled persons in all phases of implementing public policies and fosters epidemiological and clinical studies, producing information about the occurrence of disabilities and incapacities. It creates, within the scope of the Single Health System (SHS), Centers of Genetic Biology as a reference for information and prevention of disabilities. Another right ensured by the Statute concerns the compulsory enrollment and inclusion of persons with disabilities in regular schools, as well as special education to individuals hospitalized for one year or more.

Legislation is there! Its postulates show that the topics housing, rehabilitation, social inclusion, education, work, and discrimination are always included. Thus, one may question: What hinders the development of disabled persons? It is believed that the answer is latent in the insistence with which these topics are reedited in current legislation: the path to social acceptance of people with disabilities is not built with orders or good intentions of some social segments.

That is the reason why legislation ensures rights and penalizes transgressors, but there are always strategies for resistance; as shown in the statement.

...now society accepts between inverted commas. Because society needs to see disabled persons' equal capacity. But society does not see that. The reason why this work is showing out there is that there is a law. If this law did not exist, if the Ministry had not insisted in passing it, things would not have changed. Disabled persons would not have chances at work, despite having the capacity, because people without disabilities were preferred. Society is still prejudiced towards disabled persons. It is noticeable. There are people, not only one or two. About $90 \%$ of society looks at you with suspicion, indifferent. There is more. You have to show, expose you capacity, so someone can see you, even if as a disabled person, but at least they will see that you are able. Society is still very prejudiced towards people with disabilities. And this prejudice is the same for all kind of disabilities ${ }^{(15)}$.

This statement names the central concept that outlines the process of social inclusion of disabled persons - tolerance. The act of tolerating ends a mix of pity and humanism; in other words, the possibility of a person simultaneously accepting someone different and also legitimize inequality.

According to liberal utilitarianism, human beings need to seek their own development and improvement, since this doctrine does not value passiveness. Human development takes place only as a consequence of individual potentials and the options made throughout life. By transferring this idea to the lives of disabled persons, the challenge presented consists in overcoming and transcending one's own limitations, and challenging what is already established. Only then can one's social place be taken. Nonetheless, for this to occur, these individuals need solidarity.

In utilitarianism, solidarity is a concept that implies the wish to make human dignity universal, take interest in the deprived population, and become concerned with the common good ${ }^{(5)}$. Solidarity grants the benefactor social acknowledgement as a moral agent ${ }^{(18)}$ and, in the case of governmental managers, contributes to minimizing the pressure from civil society for more effective actions in view of social inequalities. This is how, through the force of the ongoing process of political and economic restructuring in Brazil, since the 1980s, people with disabilities have counted on support from the government, as well as from associations of disabled persons and non-governmental and religious organizations, among others. However, it cannot be stated that it is easy for individuals from this social segment to enhance their potentials.

Concerning disabled persons, an equitable society is one that, free from prejudice, ensures its associates the resources needed and suitable life conditions. That society pursues universal education, offers an inclusive job market, and promotes work as a right and an opportunity for all. Moreover, this society ensures equality in terms of access to goods and quality services.

However, in terms of human resource training to take care of disabled persons, there is a persisting challenge to develop a pedagogy centered on the needs of these individuals and their families. In this respect, and according to research results, nursing programs offered in the Brazilian Northeast include, in their curriculum, topics related to prevention and rehabilitation of disabled persons, adopting a biological focus. However, there are no topics related to human development and the consequent inclusion of these individuals in society ${ }^{(21)}$.

Over the past years, Brazilian nursing professionals have progressively engaged in a conduct marked by the politics and commitment to meet specific demands by SHS clients. The ability to critically reflect on the social conjuncture encourages these 
professionals to engage in equitable behaviors, supported on political and social elements involving citizenship and the possibility of interventions in public policies. Hence, it is inferred that Brazilian nursing professionals have a solidarity-oriented practice.

\section{GENERAL CONSIDERATIONS}

Brazil is a country in which the socioeconomic inequality exerts a strong impact on a large part of its population. As a result, the people below the poverty line do not manage to attend to their basic needs of survival.

The economic parameters of social justice, such as the Gine Coefficient, which guide income distribution research, demonstrate that, in Brazil, only $10 \%$ of the population concentrates significant per capita income levels, which guarantees the status of the country's richest segment to this social group.

\section{REFERENCES}

1. Hoffman K, Centeno MA. Um continente entortado (América Latina). Tempo Soc 2006 novembro; 18(2):11-46.

2. Lei no 7.853, de 24 de outubro de 1989 (BR). Dispõe sobre o apoio às pessoas portadoras de deficiência, sua integração social, sobre a Coordenadoria Nacional para Integração da Pessoa Portadora de Deficiência - CORDE institui a tutela jurisdicional de interesses coletivos ou difusos dessas pessoas, disciplina a atuação do Ministério Público, define crimes, e dá outras providências. [on line]. [Acesso em 2007 fevereiro 11]. Disponível em: http://www.planalto.gov.br/ 3. Decreto $n^{0} 3.298$, de 20 de dezembro de 1999 (BR). Regulamenta a Lei $\mathrm{n}^{0} 7.853$, de 24 de outubro de 1989. Dispõe sobre a Política Nacional para a Integração da Pessoa Portadora de Deficiência, consolida as normas de proteção, e dá outras providências. [on line]. [Acesso 2007 fevereiro 11]. Disponível em: http://www.mj.gov.br/sedh/ct/corde/dpdh/ sicorde/principal.asp

4. Lei no 10.098 , de 19 de dezembro de 2000, que estabelece normas gerais e critério básicos para a promoção da acessibilidade das pessoas portadoras de deficiência ou com mobilidade reduzida, e dá outras providências (BR). [on line]. [Acesso em 2007 fevereiro 11]. Disponível em: http:// www.mj.gov.br/sedh/ct/corde/dpdh/sicorde/principal.asp 5. Mill JS. Utilitarismo. São Paulo: Gradiva; 2005.

6. Karina IPB, Cabrera M, Macadar D. La pobreza y la desigualdad en la América Latina. Montevideo: Instituto del tercer Mundo; 2004. (Cuadernos Ocasionales Social Watch, 4).

7. Souza AP. Por uma política de metas de redução da pobreza. São Paulo Perspec 2004 outubro-dezembro; 18(4):20-7.
Thus, based on the Human Development Index (HDI), instruction level and education are directly related with the wealth and, consequently, with the well-being and longevity of a given population. It is considered that the expressive unequal distribution in Brazil determines the increasing impoverishment of the population and jeopardizes the development of different social segments, such as disabled people.

Although this group has already conquered specific legislation that guarantees its rights to citizenship, these people, subject to precarious social conditions, face difficulties to overcome poverty and achieve human development, due to limiting factors. These factors refer to health, education and work. Hence, the hypothesis is confirmed according to which liberal utilitarianism is responsible for turning the reduction of poverty more difficult and for blocking these people's development.

8. Dedecca CS, Rosandiski EN, Barbieri CV, Adriana J. Salário mínimo, benefício previdenciário e as famílias de baixa renda. Rev Bras Estud Popul 2006 julho-dezembro; 23(2):317-29. 9. Barata RB, Ribeiro MCSA. Correlation between homicide rates and economic indicators in São Paulo, Brazil, 1996. Rev Panam Salud Publica. 2000 February; 7(2):118-24.

10. Smith A. A riqueza das nações. $2^{a}$ ed. São Paulo: Martins Fontes; 2003

11. Singer P. Uma utopia militante: repensando o socialismo. Petrópolis: Vozes; 1998.

12. Mendes HWB, Caldas J, Antonio L. Prática profissional e ética no contexto das políticas de saúde. Rev Latino-am Enfermagem 2001 maio; 9(3):20-6.

13. Instituto Brasileiro de Geografia e Estatística (BR) Censo 2000. Rio de Janeiro; 2003.

14. Fundação Getúlio Vargas. Instituto Brasileiro de Economia. Retratos da deficiência no Brasil. [on line]. [Acesso em 2007 fevereiro 10]. Disponível em: http://www.fgv.br/cps/ Retratos_Deficiencia_Brasil.cfm

15. França ISX, Pagliuca LMF. Formas de sociabilidade e instauração da alteridade: vivência das pessoas com necessidades especiais. [tese]. Fortaleza: Universidade Federal do Ceará; 2004.

16. Lei 8742 de 7 de dezembro de 1993 (BR). Dispõe sobre a organização da Assistência Social e dá outras providências. [on line] [Acesso em 2007 fevereiro 11]. Disponível em: http://www.mj.gov.br/sedh/ct/corde/dpdh/sicorde/ principal.asp

17. Vinod T. O Brasil visto por dentro. Rio de Janeiro: José Olympio; 2005.

18. Caponi S. Da compaixão à solidariedade: uma genealogia da assistência médica. Rio de Janeiro: Fiocruz; 2000. 
19. Constituição da República Federativa do Brasil de 1988. [on line] [Acesso em 2007 janeiro 25]. Disponível em: http:/ /www.planalto.gov.br/ccivil_03/Constituicao/

20. Brasil. Projeto de Lei no 3638, de 09 de outubro de 2000, institui o Estatuto do Portador de Necessidades Especiais e dá outras providências. [on line] [Acesso em 2007 fevereiro 10]. Disponível em: http://intervox.nce.ufrj.br/ candido/leis/ plei3638.htm

21. França ISX, Pagliuca LMF, Nóbrega RA. Discurso políticoacadêmico e integração das pessoas com deficiência: das aparências aos sentidos. Rev ESc Enfermagem USP 2003 dezembro; 4(37):24-33. 